\title{
miRNA Expression Profiling in Pediatric B-Cell Acute Lymphoblastic Leukemia by Microarray Technology
}

\author{
EMAN EL-SHARAWY, M.Sc. ${ }^{1}$; MOHAMED EL-SHANSHQRY, M.D. ${ }^{2}$; SAID ABDOU, M.D. ${ }^{3}$; \\ LAILA M. SHREIF, M.D. ${ }^{4}$; ABDEL-AZIZ A. ZIDAN, Ph.D. ${ }^{5}$ and ENAS A.A. BAKI, Ph.D. ${ }^{6}$ \\ The Departments of Pediatric, Tanta Cancer Center and Children's Cancer Hospital 57357, Egypt ${ }^{1}$, Pediatric Hematology/Oncology \\ Unit, Faculty of Medicine, Tanta University ${ }^{2}$, Clinical Pathology, Faculty of Medicine, Tanta University ${ }^{3}$, Pediatric Hematology \\ /Oncology Unit, Pediatric, Faculty of Medicine, Zagazig University ${ }^{4}$, Zoology, Faculty of Science, Damanhour University ${ }^{5}$ and \\ Immunology \& Biotechnology Unit, Zoology, Faculty of Science , Tanta University, Egypt
}

\begin{abstract}
Background: MicroRNAs (miRNAs) are endogenous noncoding RNAs, which play an essential role in the regulation of gene expression.

Aim of the work: To analyze miRNA expression profile in the childhood B acute lymphoblastic leukemia (B-ALL) To understand the functional regulatory effects of differential miRNAs on their targets and its clinical significance and novel analytical method to combine their expression profiles.

Patients and Methods: In this study, we determined the relative expression analysis of miRNA and mRNA profiles in 20 childrenB-ALL patients. Through the use of miRNA microarray technology and according to their miRNA profile. The best characterized non-coding RNA family consists in humans of about 1400 microRNAs for which abundant evidence have demonstrated fundamental importance in normal development, differentiation, growth control and inhuman diseases such as cancer.
\end{abstract}

Results: miR-100, miR-146a, miR-128a, miR-128b, miR181a, miR-34, miR-193a, miR-193b, miR-151, miR-130b, and miR-125b were found to be the most consistently upregulated miRNAs in B-acute lymphoblastic leukemia patients as compared with healthy control.

Conclusion: To analyze miRNA in B-ALL children patients before and after induction of chemotherapy and measure the correlation of these results using microarray technique.

Key Words: miRNA - B-ALL - Microarray - Expression profile - Children ALL.

Key Message: miRNA s are very important in diagnosis and prognosis of childhood leukemia.

Correspondence to: Dr. Eman El-Sharawy, The Department of Pediatric, Tanta Cancer Center and Children's Cancer Hospital 57357, Egypt

\section{Introduction}

ACUTE lymphoblastic leukemia (ALL) is the most common malignancy diagnosed in children [1]. Patients with ALL receive intensive courses of chemotherapy which are followed by a period of leukopenia, Approximately three-quarters of patients express this common B-ALL precursor [2] The introduction of the microarray technology has more recently allowed to identify specific signatures that are associated with ALL [3]

MicroRNAs (miRNAs) are endogenous noncoding RNAs, which play an essential role in the regulation of gene expression. This study was carried out to analyze miRNA expression profile in acute lymphoblasticleukemia. As Aberrant expression of miRNA has been observed in many types of cancer, showing either tumor suppressive or oncogenic activity [4]

With miRNA microarray technology, and according to their miRNA profile, About $1400 \mathrm{mi}-$ croRNAs have demonstrated importance in normal development, differentiation, growth control inhuman diseases such as cancer [5] .

According to, miRNAs influence numerous cancer-relevant processes such as proliferation, cell cycle control, apoptosis, differentiation, migration and metabolism. It seems that this miRNA has a basic role during differentiation of lymphocytes and its function depends on the expression and repression of other genes, transcription factors and miRNAs. Indicates that these miRNAs may be probable factors involved in the pathogenesis of ALL and might be potential diagnosis biomarkers and therapeutic targets in the future [6]. The aim 
of this work was to study the potential of microRNA gene expression profile of pediatric patient with acute lymphoblastic leukemia and its clinical significance.

\section{Patients and Methods}

After obtaining the research ethics committee approval (approval code: 3037/01/15) and informed written consent was taken from patient guardians, aprospective randomized double blind study was carried outin Tanta University Hospitalsin Pediatric Departmentfor one year (from May 2015 till May 2016).

\section{Patients and healthy control:}

This study was conducted on 20 children with $\mathrm{B}$ acute lymphoblastic leukemia before induction of chemotherapy. This group was compared to 20 healthy children matched for age and sex. Patients were recruited from Tanta Cancer Center, and Hematology/Oncology Unit, Pediatric Departments, Tanta University Hospital, Tanta, Egypt. The study conducted after the approval of the ethical committee at Faculty of Medicine, Tanta University, Egypt.

\section{Inclusion criteria:}

Pediatric patients diagnosed as B acute lymphoblastic leukemia and their age under 18 years old.

\section{Exclusion criteria:}

Pediatric oncological patients not diagnosed as ALL; (hematological and solid malignancies) and B-ALL patient under therapy or end treatment or in complete remission.

\section{Data of the patient:}

All patient was subjected to full history taken, complete clinical examination and laboratory investigation in the form of: Complete blood picture "CBC", biochemical profile, liver function test, kidney function test, Bone marrow aspirate and immunophenotyping. After confirm diagnosis all patients were treated with total XV protocols including high risk \& low risk protocol.

\section{Collection of blood samples:}

Whole blood was collected in Vacuette EDTA K3E blood bottles (Grenier Bioone); one processed for plasma, another unprocessed, and a third sample collected in Vacutainer Serum Separator Tubes II (Becton Dickinson) for serum. Samples for serum collection were left to clot at room temperature for 30 minutes and then all samples destined for serum and plasma collection were centrifuged at
2000 rpm @ 4 ${ }^{\circ} \mathrm{C}$ for 10 minutes. Plasma/serum was removed, aliquoted and stored at $-20^{\circ} \mathrm{C}$ until required. The unprocessed whole blood Sample was stored at $4^{\circ} \mathrm{C}$ until required.

\section{Patient diagnosis:}

Bone marrow aspirate was used to confirm the presence of leukemic blasts using laboratory microscopic investigation followed by immunophenotyping using flow cytometry to identify the subtype of acute leukemia using the routinely diagnostic antibodies, including: CD 19, CD 10, HLA-DR, CD34, and Terminal Deoxynucleotidyl Transferase (TdT) for 20 patients. B-ALL patients with blasts were positive for CD 19, CD 10, HLADR, CD34, TdT, and negative for CD3, CD33, CD117, and Myeloperoxidase (MPO) (BD Biosciences, CA, USA).

\section{Purification of miRNA from B-ALL patients:}

Small RNA (miRNA) fractions $(<200$ nucleotides) were extracted from whole blood samples using TRIzol (Invitrogen) in combination with RNeasy Mini Kit from Qiagen. The method combines phenol/guanidine based lysis and silicon membrane-based purification of total RNA [7] . In brief 250 thawed serum/plasma was mixed with $1 \mathrm{~mL}$ QIAzol@ lysis reagent. By adding 250 chloroform, the homogenate was separated into three phases. The upper phase of clear liquid contained RNA and was used for further extraction of RNA. The addition of ethanol optimizes the binding conditions of all RNA molecules above 18 nucleotides. All the samples were run through an RNeasy Mini spin column where total RNA binds to the column membrane while phenol and other impurities are washed away. Contaminating DNA was removed by on-column Dnase digestion. RNA was eluated from the column using 30 Lof Rase-free water. A small volume of the purified RNA was used for quantitative and qualitative analysis.

\section{Results}

\section{Patient's demographic:}

The age of B-ALL patients and control groups were ranged from (1.0 to 18.0) years with a mean of 9.95 \pm 5.45 years in ALL group and $11.30 \pm 0.92$ years in control group. There was no significant difference in the age between the studied groups according to Chi square test and Mann Whitney test $(\mathrm{F}$-test $=1.124$ and $p$-value $=0.738)$. In addition, there was no significant difference between the studied groups as regard to sex distribution according to chi-square test $\left(\mathrm{X}^{2}=0.000\right.$ and $p$-value $=1.000)$. As shown in Table (1). 
Diagnosis of B-Acute lymphoblastic leukemia:

Bone marrow aspiration (BMA) is the conclusive tool for diagnosis of ALL. As shown in Table (2), the mean level of blast cell in patients group was $32.03 \%$. As regard BMA mean level was $20.08 \%$ in patients group. BMA was performed in day 15 , and mean level was $1.61 \%$ in patients group. Minimal residual disease (MRD) mean level was $0.19 \%$ in patients group.

\section{$C B C$ analysis in ALL patients:}

Initial complete blood picture (CBC) performance is a critical step in leukemia diagnosis, as picture of pancytopenia may represent hypocellular bone marrow with decreased marrow activity as shown in Table (3). Moreover, many cases of ALL patients presented with high total leukocytic count (TLC), the range of white blood cells (WBCs) count was $2.67 \overline{3} 80.0 \mathrm{c} / \mathrm{mm}^{3}$ with a mean of $29.0 \pm 25.34 \mathrm{c} / \mathrm{mm}$ and in control group, the range of white blood cells count were $4.0-7.50 \mathrm{c} / \mathrm{mm}$ with a mean of $5.24 \pm 1.15 \mathrm{c} / \mathrm{mm} 3$. There were significant differences between two studied groups as regard to hemoglobin concentration (Utest $=6.000$ and $p$-value $<0.001 *$ (*) and platelets count (U-test $=0.000 *$ and $p$-value ${ }^{\circ .001 *}$ using student $t$-test. Non-significant differences were detected between the studied groups as regard to white blood cells using student $t$-test (U-test $=69.000)$ and $(p$-value $=<0.001)$.

The total number of screened miRNAs was 5639 genes by using miRNA-4.0 array (Affymetrix ${ }^{\circledR}$ ). We found that 474 genes were differentially expressed when compared B-ALL with healthy control. From these genes, 187 genes are up-regulated, and 287 genes were down-regulated.These are some of the highly significant miRNA that is associated with cytogenetic abnormalities in ALL and its altered expression may lead to leukemogenesis by causing deleterious effect on normal immune function such as hsa-mir-193a, hsa-mir-193b, and hsa-mir-130b as shown in Fig. (1), Table (4).

Table (1): Comparison between the two studied groups according to demographic data.

\begin{tabular}{lllllll}
\hline & \multicolumn{2}{c}{$\begin{array}{c}\text { Cases } \\
(\mathrm{n}=20)\end{array}$} & \multicolumn{2}{c}{$\begin{array}{c}\text { Control } \\
(\mathrm{n}=20)\end{array}$} & $\begin{array}{c}\text { Test of } \\
\text { Sig. }\end{array}$ & $p$ \\
\cline { 2 - 5 } & No & $\%$ & No & $\%$ & & \\
\hline Sex: & 12 & 60.0 & 12 & 60.0 & $\chi^{2}=$ & 1.000 \\
$\quad$ Male & 8 & 40.0 & 8 & 40.0 & 0.000 & \\
$\quad$ Female & & & & & & \\
Age (years): & & & & & & \\
$\quad$ Range & $1.50-17.0$ & $10.0-13.0$ & $\mathrm{U}=$ & \\
$\quad \begin{array}{l}\text { Mean } \pm \mathrm{SD} \\
\text { Median }\end{array}$ & $9.95 \pm 5.45$ & $11.30 \pm 0.92$ & 187.00 & 0.738 \\
\hline
\end{tabular}

Table (2): Descriptive analysis of the studied cases according to different parameters (Bone Marrow) $(n=20)$.

\begin{tabular}{llll}
\hline & \multicolumn{1}{c}{ Rang } & Mean \pm SD & Median \\
\hline Peripheral BLAST (\%) & $0.0-84.0$ & $37.20 \pm 32.03$ & 32.50 \\
BMA (\%) & $30.0-94.0$ & $67.90 \pm 20.08$ & 71.0 \\
BM D15 (\%) & $0.0-5.0$ & $1.95 \pm 1.61$ & 2.0 \\
MRD (\%) & $0.0-0.58$ & $0.14 \pm 0.19$ & 0.03 \\
\hline
\end{tabular}

Table (3): Comparison between the two studied groups according to ${ }^{\mathrm{CBC}}{ }^{*}$, statistically significant at $p \leq 0.05$.

\begin{tabular}{|c|c|c|c|c|}
\hline & $\begin{array}{l}\text { Cases } \\
(\mathrm{n}=20)\end{array}$ & $\begin{array}{l}\text { Control } \\
(\mathrm{n}=20)\end{array}$ & $\begin{array}{l}\text { Test of } \\
\text { Sig. }\end{array}$ & $p$ \\
\hline \multicolumn{5}{|l|}{ T.L.C $\left(x 10^{3}\right)$ : } \\
\hline Range & $2.67-80.0$ & $4.0-7.50$ & $\mathrm{U}=$ & \multirow{3}{*}{$<0.001 *$} \\
\hline Mean $\pm \mathrm{SD}$ & $29.0 \pm 25.34$ & $5.24 \pm 1.15$ & $69.0^{*}$ & \\
\hline Median & 23.60 & 4.80 & & \\
\hline \multicolumn{5}{|l|}{$H B(g / d l):$} \\
\hline Range. & $5.0-10.0$ & $12.0-15.0$ & $\mathrm{U}$ & \multirow{3}{*}{$<0.001 *$} \\
\hline Mean \pm SD & $7.62 \pm 1.34$ & $13.40 \pm 0.94$ & $=0.0 *$ & \\
\hline Median & 7.60 & 13.50 & & \\
\hline \multicolumn{5}{|l|}{ Platelet $\times 10^{3}$} \\
\hline Range & $12.0-54.0$ & $150.0-450.0$ & $\mathrm{U}$ & \multirow[t]{3}{*}{$<0.001 *$} \\
\hline Mean \pm SD & $30.70 \pm 12.19$ & $157.40 \pm 7.79$ & $=0.0 *$ & \\
\hline Median & 30.0 & 150.0 & & \\
\hline
\end{tabular}

Table (4): Comparison between the two studied groups according to miRNA (193a, 193b, 130b).

\begin{tabular}{|c|c|c|c|}
\hline \multirow{2}{*}{ miRNA } & Pati & 20) & \multirow{2}{*}{$\begin{array}{l}\text { Control } \\
(\mathrm{n}=20)\end{array}$} \\
\hline & Before & After & \\
\hline
\end{tabular}

hsa-mir-193 a:

$\begin{array}{llll}\text { Min }- \text { Max } & 0.12-7.12 & 4.01-11.65 & 0.03-1.41 \\ \text { Mean } \pm \text { SD } & 3.17 \pm 2.07 & 8.48 \pm 1.98 & 0.42 \pm 0.39 \\ \text { Median } & 3.0 & 8.65 & 0.33\end{array}$

Test of sig.

$p_{1}<0.001 *, p_{2}<0.001 *, p_{3}<0.001 *$

hsa-mir-193 b:

$\begin{array}{llll}\text { Min }- \text { Max } & 0.16-8.31 & 5.01-11.02 & 0.02-3.70 \\ \text { Mean } \pm \text { SD } & 3.14 \pm 2.41 & 8.44 \pm 1.66 & 0.71 \pm 1.11 \\ \text { Median } & 2.51 & 8.59 & 0.22\end{array}$

Test of sig. $\quad p_{1}<0.001^{*}, p_{2}<0.001^{*}, p_{3}<0.001^{*}$

hsa-mir-130 b:

$\begin{array}{llll}\text { Min }- \text { Max } & & & \\ \text { Mean } \pm \text { SD } & 0.21-8.65 & 4.26-10.65 & 0.02-1.48 \\ \text { Median } & 3.47 \pm 2.31 & 8.16 \pm 1.72 & 0.29 \pm 0.42 \\ & 3.58 & 8.56 & 0.19 \\ \text { Test of sig. } & p_{1}<0.001 *, p_{2}<0.001 *, p_{3}<0.001 *\end{array}$




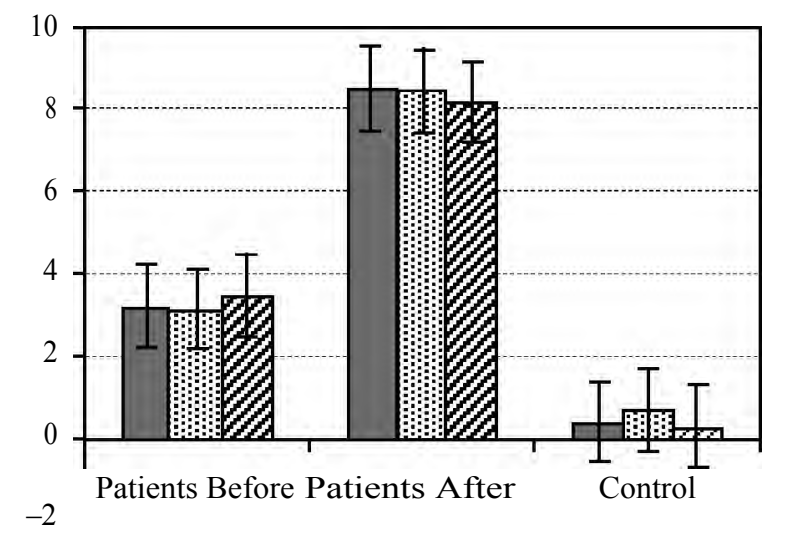

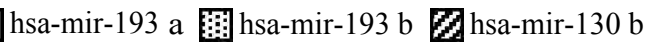

Fig. (1): miRNA relative expression in B-ALL patients before induction of chemotherapy.

\section{Discussion}

Microarray technology has been extensively used in hope to create a gene signature that will allow us to predict cancer [8]. Microarray expression data from a wide spectrum of cancer diseases have since evidenced that aberrant miRNA expression is the rule rather than the exception in cancer [8]. The emergence of miRNA microarrays and their use in prognostic research have made it possible to believe that miRNAs give a more reliable view of the transcriptional program as it regulates mRNA at the post-transcriptional level and has been proven to give more reliable results than mRNA profiling regarding classification of tumors and the diagnostic and prognostic validity of gene profiling.

The best characterized non-coding RNA family consists in humans of about 1400 microRNAs for which abundant evidence have demonstrated fundamental importance in normal development, differentiation, growth control and inhuman diseases such as cancer. In Accordingly, miRNAs influence numerous cancer-relevant processes such as proliferation, cell cycle control, apoptosis, differentiation, migration and metabolism [5]. In this study, we determined the relative expression analysis of miRNA and mRNA profiles in 20 ALL patients. To understand the functional regulatory effects of differential miRNAs on their targets and its clinical significance, we used a novel analytical method to combine their expression profiles.

First, we sought to identify miRNAs specifically expressed in various B-ALL before induction phase of chemotherapy and to carry out an analysis of gene and miRNA expression profiles to highlight putative miRNA targets that might be involved in leukemogenesis. There are many miRNAs that are thought to play a role in tumorigenesis with some of themacting as oncogenes and promote cancer, whereas others function as tumor suppressors and preventing cancer.

Reportedly, miR-100 is involved in the tumorigenesis and tumor progression of several cancer types. Our data showed that miR-100 expression was up-regulated before induction of chemotherapy in B-ALL patients when compared with normal group. Recently, many studies have confirmed that miR- 100 can regulate multiple genes to induce the cell apoptosis in many types of mammalian cell lines. There is a growing body of evidence that miR-100 inhibits the progression of apoptosis in human cancer cells through multiple pathways.

miR-128a and miR-128b expression were increased upon after induction of chemotherapy in B-ALL patients when compared with before induction and normal group. miR-128 increased DNA damage, which suggesting that these patients maybe more susceptible to DNA damaging agents. Previous studies have shown that miR-128a and b acts as an oncogene in malignancies such as acute leukemia, breast cancer, and lung cancer.

\section{References}

1- IDRIS S-Z., HASSAN N., LEE L-J., MD NOOR S., OSMAN R., ABDUL-JALIL M., NORDIN A-J. and ABDULLAH M.: Increased regulatory T cells in acute lymphoblastic leukaemia patients. Hematology, 21 (4): 206$212,2016$.

2- SALEM M.L., EL-SHANSHORY M.R., EL-DESOUKI N.I., ABDOU S.H., ATTIA M.A., ZIDAN A-AA. and MOURAD S.S.: Children with acute lymphoblastic leukemia show high numbers of CD4+ and CD8+ T-cells whichare reduced by conventional chemotherapy. Clinical Cancer Investigation Journal, 4 (5): 603, 2015.

3- NUCERA S., GIUSTACCHINI A., BOCCALATTE F., CALABRIA A., FANCIULLO C., PLATI T., RANGHETTI A., GARCIA-MANTEIGA J., CITTARO D. and BENEDICENTI F.: miRNA-126 orchestrates an oncogenic program in B cell precursor acute lymphoblastic leukemia. Cancer Cell, 29 (6): 905-921, 2016.

4- MACFARLANE L.A. and MURPHY P.R.: MicroRNA: Biogenesis, Function and Role in Cancer. Current Genomics, 11 (7): 537-561, 2010.

5- JANSSON M.D. and LUND A.H.: MicroRNA and cancer. Molecular Oncology, 6 (6): 590-610, 2012.

6- LIZ J. and ESTELLER M.: lncRNAs and microRNAs witha role in cancer development. Biochimica et Biophysica Acta (BBA)-Gene Regulatory Mechanisms, 1859 (1): 169-176, 2016. 
7- CHOMCZYNSKI P. and SACCHI N.: The single-step method of RNA isolation by acid guanidinium thiocyanatephenol-chloroform extraction: Twenty-something years on. Nature Protocols, 1 (2): 581-585, 2006.

8- PATEL S., MASON C.C., GLENN M.J., PAXTON C.N., SOUTH S.T., CESSNA M.H., ASCH J., COBAIN E.F.,
BIXBY D.L., SMITH L.B., RESHMI S., GASTIERFOSTER J.M., SCHIFFMAN J.D. and MILES R.R.: (2017) Genomic analysis of adult B-ALL identifies potential markers of shorter survival. Leukemia Research, 56: 44-51, 2017.

9- MUNKER R. and CALIN G.A.: MicroRNA profiling in cancer. Clin. Sci. (Lond), 121 (4): 141-158, 2011.

\section{الميكرو ار ان أيه فى الأطفال المصابين بسرطان

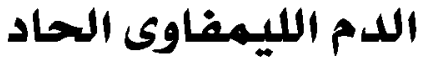

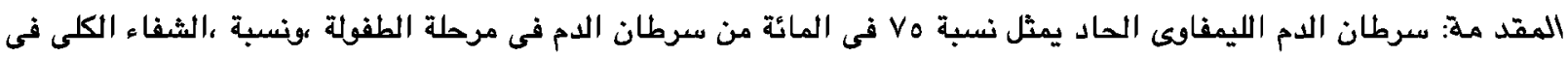

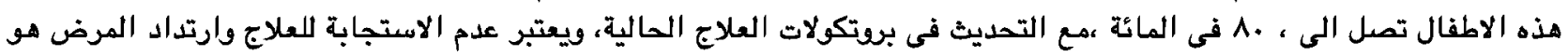

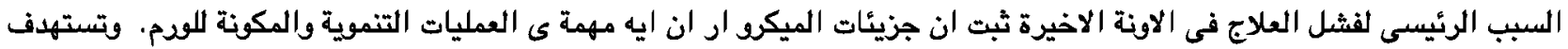

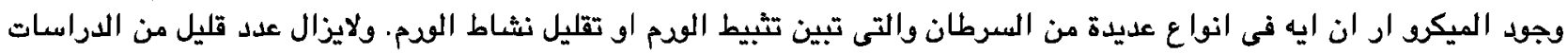

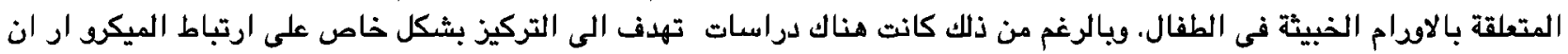

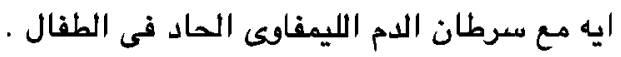

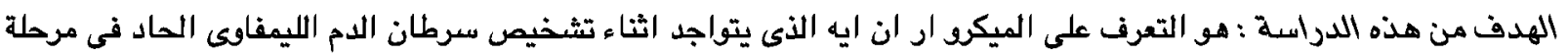

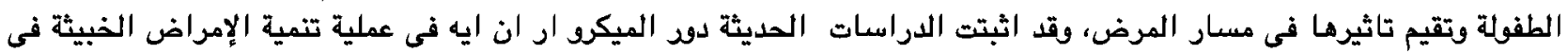

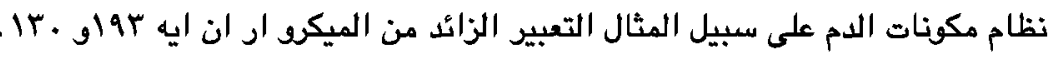

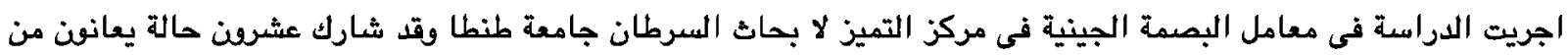

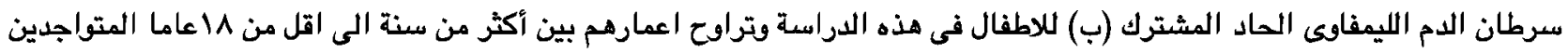

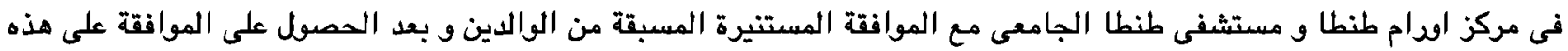

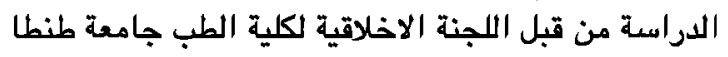

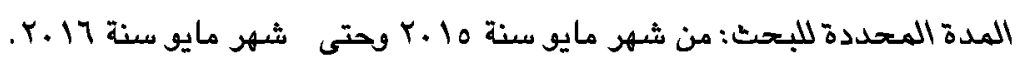

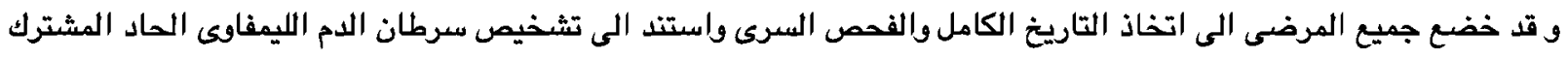

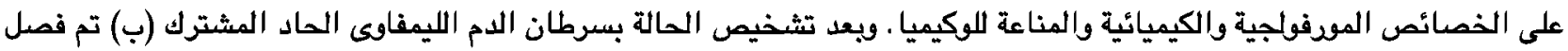

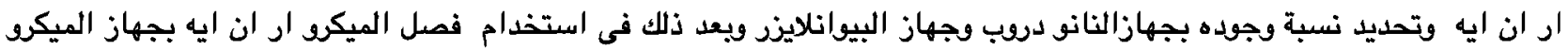

